\title{
ASUPAN MAKANAN SUMBER ANTIOKSIDAN DAN KADAR GLUKOSA DARAH PUASA PADA PENDERITA DM TIPE 2 DI JAWA TIMUR
}

\author{
Kanthi Permaningtyas Tritisari ${ }^{\star 凶}$, Dian Handayani* Ayuningtyas Dian Ariestiningsih*, \\ Inggita Kusumastuty*
}

\begin{abstract}
Abstrak
Penyakit DM tipe 2 pada perkembangannya dapat menimbulkan stres oksidatif yang mengakibatkan terjadinya perubahan aktivitas antioksidan endogen dan juga meningkatnya kerusakan biomolekul secara oksidatif. Kondisi ini menyebabkan penderita DM tipe 2 memerlukan asupan antioksidan eksogen dalam jumlah besar untuk menghambat kerusakan oksidatif di dalam tubuh. Penelitian ini bertujuan untuk mengetahui hubungan antara asupan makanan sumber antioksidan dengan kadar glukosa darah puasa pada penderita DM tipe 2 di Jawa Timur. Penelitian ini merupakan penelitian cross sectional pada penderita DM tipe 2 di 4 Kota dan Kabupaten di Jawa Timur. Pengambilan sampel dengan cara purposive sampling, dengan jumlah sampel sebanyak 160 responden. Makanan sumber antioksidan pada penelitian ini adalah makanan sumber vitamin A, vitamin C, vitamin E. Data asupan antioksidan diperoleh dari hasil dietary assessment SQ FFQ, sedangkan kadar glukosa darah diperoleh dari pemeriksaan laboratorium. Hasil analisis korelasi menunjukkan bahwa tidak ada hubungan antara asupan vitamin $A(p=0,185)$, vitamin $C(p$ $=0,057)$, dan vitamin $E(p=0,211)$ dengan kadar glukosa darah puasa. Dapat disimpulkan bahwa tidak ada hubungan antara asupan makanan sumber antioksidan dengan kadar glukosa darah puasa penderita DM tipe 2 di Jawa Timur.
\end{abstract}

Kata kunci: antioksidan, DM tipe 2, glukosa darah puasa, SQ FFQ, vitamin

\section{INTAKE OF THE FOOD SOURCES OF ANTIOXIDANTS WITH FASTING BLOOD GLUCOSE LEVELS IN PEOPLE WITH TYPE 2 DM IN EAST JAVA}

\begin{abstract}
Type 2 DM development may cause oxidative stress resulting in a change of endogenous antioxidant activity, also increase in oxidative bio-molecular damage. This condition causes type $2 \mathrm{DM}$ patients require exogenous antioxidants in large quantities to inhibit oxidative damage in the body. This research aimed was to know the correlation between intake of the food sources of antioxidants with fasting blood glucose levels in people with type 2 DM in East Java. This research used a cross sectional method in people with type 2 DM in four cities and regencies in East Java. The food sources of antioxidant were the foods contain of vitamin A, vitamin $\mathrm{C}$ and vitamin $\mathrm{E}$. The data were collected by using purposive sampling, with the total number of 160 respondents. Antioxidant intake data were obtained from the results of dietary assessment SQ-FFQ and blood glucose levels were obtained from the results of the laboratory. Correlation analysis showed that there was nocorrelationbetween the intake of vitamin $A(p=0.185)$, vitamin $C(p=$ $0.057)$ and vitamin $E(p=0.211)$ and fasting blood glucose levels. Thus, it can be concluded that there was no correlation between the intake of food sources of antioxidants with fasting blood glucose levels of type 2 DM patients in East Java
\end{abstract}

Keywords: antioxidant, type $2 \mathrm{DM}$, fasting blood glucose, SQ- FFQ, vitamin

* Program Studi IImu Gizi, FK UB

EE-mail: tritisari@gmail.com 


\section{Pendahuluan}

Diabetes mellitus (DM) merupakan suatu penyakit metabolik yang cenderung meningkat prevalensinya di dunia, termasuk di Indonesia. Berdasarkan data IDF, terjadi peningkatan jumlah penderita DM di Indonesia dari 7,6 juta penduduk pada tahun 2013 menjadi 9,1 juta pada tahun 2014. Kondisi ini membuat Indonesia menempati peringkat ke-5 penyandang DM terbanyak di dunia. ${ }^{1}$ Hasil Riskesdas (2013) menunjukkan prevalensi DM di Indonesia yang terdiagnosis dokter atau gejala sebesar $2,1 \%$. Salah satu propinsi di Indonesia yang perlu mendapatkan perhatian adalah Propinsi Jawa Timur karena memiliki prevalensi DM di atas prevalensi nasional, yaitu sebesar 2,5\%. Selain itu, data RISKESDAS juga menunjukkan bahwa di Jawa Timur terjadi peningkatan prevalensi dari tahun 2007 yaitu 1,3\% menjadi 2,5\% tahun 2013. ${ }^{2}$

Diabetes mellitus tipe 2 merupakan kelainan metabolik yang ditandai dengan adanya hiperglikemi. Hiperglikemi pada DM disebabkan oleh adanya kelainan sekresi insulin dan kerja insulin atau keduanya. ${ }^{3}$ Penyakit DM tipe2 pada perkembangannya dapat menimbulkan stres oksidatif yang ditandai oleh ketidakseimbangan antara oksidan dan antioksidan dalam tubuh. Pada kondisi stres oksidatif terjadi perubahan aktivitas antioksidan endogen dan juga meningkatnya kerusakan biomolekul secara oksidatif. ${ }^{4}$ Pada penderita DM ditemukan terjadi penurunan kadar vitamin antioksidan A, C, dan E. Hal ini kemungkinan disebabkan oleh peningkatan kebutuhan untuk mengontrol stres oksidatif yang berlebihan akibat kelainan dalam metabolisme glukosa. ${ }^{5}$

Peningkatan stres oksidatif menyebabkan penderita DM tipe 2 memerlukan asupan antioksidan eksogen dalam jumlah besar untuk menghambat kerusakan oksidatif di dalam tubuh. ${ }^{4,6}$ Pada suatu penelitian menunjukkan hasil bahwa asupan vitamin $\mathrm{E}$, asupan alpha-tocopherol, gamma-tocopherol, delta-tokoferol, dan beta-tocotrienol berbanding terbalik dengan risiko terjadinya DM tipe $2 .{ }^{7}$ Hasil penelitian lain menyebutkan bahwa pemberian suplementasi vitamin C selama 3 bulan sebanyak 266,7 mg/hari mampu mengubah kadar glukosa darah puasa (GDP). ${ }^{8}$ Berdasarkan latar belakang tersebut, maka tujuan penelitian ini adalah mengetahui gambaran asupan makanan sumber antioksidan (vitamin A, C, dan E) pada penderita DM tipe 2 di Jawa Timur dan hubungannya dengan kadar glukosa darah puasa.

\section{Bahan dan Metode}

Penelitian ini merupakan penelitian deskriptif observasional dengan metode cross sectional menggunakan sampel penderita DM tipe 2 di Instalasi Rawat Jalan di Rumah Sakit atau Puskesmas. Lokasi penelitian di 4 Kota dan Kabupaten di Jawa Timur, yaitu Kota Surabaya, Kabupaten Bangkalan, Kota Malang, dan Kabupaten Lamongan. Pengambilan sampel dengan cara purposive sampling, dengan kriteria inklusi yaitu penderita DM tipe 2 yang bersedia dijadikan responden, bisa berkomunikasi verbal dengan baik serta berusia 40-59 tahun. Kriteria eksklusi meliputi penderita DM tipe 2 yang tidak kooperatif dan sedang hamil atau menyusui. Perhitungan besar sampel menggunakan rumus Lemeshow didapatkan sampel sebanyak 160 responden.

Data yang dikumpulkan adalah data asupan makanan sumber antioksidan meliputi vitamin $A$, vitamin $C$, dan vitamin $E$ (diperoleh dari hasil dietary assessment $\mathrm{SQ}$ FFQ yang diolah menggunakan program nutrisurvey kemudian dibandingkan dengan kebutuhan sehari. Asupan vitamin A 
dikatakan cukup jika asupan $\geq 100 \%$ total kebutuhan sehari $(600 \mathrm{mcg})$ dan kurang jika asupan $<100 \%$, vitamin $C$ dikatakan cukup jika asupan $\geq 100 \%$ total kebutuhan sehari (266,7 mg) dan asupan kurang jika <100\%), sedangkan vitamin E dikatakan cukup jika asupan $\geq 100 \%$ total kebutuhan sehari (300 IU) dan kurang jika asupan $<100 \%$. Kadar glukosa darah puasa (dikatakan terkendali jika $<126 \mathrm{mg} / \mathrm{dL}$ atau tidak terkendali $>126 \mathrm{mg} / \mathrm{dL}$ yang diperoleh dari hasil pemeriksaan laboratorium terbaru (maksimal 1 minggu terakhir).3,8

Analisis statistk yang digunakan adalah uji korelasi Pearson dan Spearman karena skala data yang digunakan adalah rasio. Penelitian ini telah mendapatkan persetujuan dari Komisi Etik Penelitian Kesehatan
Fakultas Kedokteran Universitas Brawijaya dengan No. 421/EC/KEPK/08/2015.

Hasil

Berdasarkan hasil penelitian diketahui bahwa mayoritas responden memiliki tingkat asupan makanan sumber vitamin $C$ dan vitamin $E$ dalam kategori kurang dari kebutuhan yang dianjurkan, sedangkan tingkat asupan makanan sumber vitamin $A$ mayoritas responden sudah tergolong baik (123 responden). Dari hasil juga diketahui mayoritas penderita DM tipe 2 yang menjadi responden memiliki kadar glukosa darah yang tidak terkendali yaitu $>126 \mathrm{mg} / \mathrm{dL}$. Data sebaran asupan makanan sumber antioksidan dan GDP disajikan dalam Tabel 1.

Tabel 1. Sebaran asupan makanan sumber antioksidan dan GDP pada penderita DM tipe 2 di Jawa Timur

\begin{tabular}{|c|c|c|c|c|}
\hline \multirow{3}{*}{ Zat Antioksidan } & \multicolumn{4}{|c|}{ GDP } \\
\hline & \multicolumn{2}{|c|}{ Tidak terkendali } & \multicolumn{2}{|c|}{ Terkendali } \\
\hline & $n$ & $\%$ & $\mathrm{n}$ & $\%$ \\
\hline \multicolumn{5}{|l|}{ Vitamin A } \\
\hline Asupan Kurang & 24 & 64,9 & 13 & 35,1 \\
\hline Asupan Baik & 93 & 75,6 & 30 & 24,4 \\
\hline \multicolumn{5}{|l|}{ Vitamin C } \\
\hline Asupan Kurang & 107 & 73,3 & 39 & 26,7 \\
\hline Asupan Baik & 10 & 71.4 & 4 & 28,6 \\
\hline \multicolumn{5}{|l|}{ Vitamin E } \\
\hline Asupan Kurang & 117 & 73,1 & 43 & 26,9 \\
\hline Asupan Baik & 0 & 0 & 0 & 0 \\
\hline
\end{tabular}

Hasil SQ FFQ menunjukkan bahwa makanan sumber vitamin $\mathrm{A}$ yang sering dikonsumsi responden adalah telur, pepaya, tomat, wortel, dan bayam, sedangkan daun pepaya dan daun singkong jarang dikonsumsi oleh responden, bahkan tidak ada responden yang mengonsumsi hati sapi yang memiliki kandungan vitamin $\mathrm{A}$ tertinggi. Makanan sumber Vitamin $C$ yang paling sering dikonsumsi responden adalah buah pepaya, pisang, jeruk, tomat, dan apel. Sedangkan makanan sumber Vitamin $E$ yang paling sering dikonsumsi adalah tempe, kacang tanah, taoge dan minyak kelapa. 
Tabel 2. Analisis hubungan asupan makanan sumber antioksidan dan GDP pada penderita DM tipe 2 di Jawa Timur

\begin{tabular}{lcc}
\hline & $\begin{array}{c}\text { Hasil analisis } \\
\text { statistik }\end{array}$ & Kadar GDP \\
\hline Asupan Makanan Sumber Vitamin A & $\mathrm{r}$ & -0.105 \\
& $\mathrm{p}$ & 0.185 \\
\hline Asupan Makanan Sumber Vitamin C & $\mathrm{r}$ & -0.150 \\
& $\mathrm{p}$ & 0.057 \\
\hline Asupan Makanan Sumber Vitamin E & $\mathrm{r}$ & -0.099 \\
& $\mathrm{p}$ & 0.211 \\
\hline
\end{tabular}

Data asupan makanan sumber vitamin $A$, vitamin $C$, dan vitamin $E$ serta kadar glukosa darah puasa yang didapat merupakan data yang tidak terdistribusi normal, sehingga dilakukan transformasi data. Hasilnya data asupan vitamin $\mathrm{C}$ dan kadar glukosa darah puasa menjadi terdistribusi normal, namun data asupan vitamin A dan vitamin $E$ tetap tidak terdistribusi normal, sehingga dalam analisis korelasi antara asupan vitamin C dan GDP menggunakan uji Pearson, sedangkan korelasi antara asupan vitamin $\mathrm{A}$ dan $\mathrm{E}$ dengan GDP menggunakan uji Spearman. Hasil uji statistik pada Tabel 2, menunjukkan bahwa tidak ada hubungan antara asupan makanan sumber vitamin $\mathrm{A}$, vitamin $\mathrm{C}$, dan vitamin $\mathrm{E}$ dengan kadar glukosa darah puasa $(p>0,05)$. Nilai korelasi $(r)$ menunjukkan angka negatif yang artinya tingkat asupan antioksidan berbanding terbalik dengan kadar glukosa darah puasa.

\section{Pembahasan}

Diabetes mellitus (DM) tipe 2 merupakan penyakit multifaktorial yang biasanya berkaitan dengan metabolisme energi, terutama karbohidrat dan lemak. Sebagian besar zat gizi mikro juga terlibat baik sebagai bagian dari penyebab atau efek patologi kronis ini. Konsekuensi dan komplikasi dari diabetes adalah hasil dari ketidakseimbangan antara pembentukan radikal bebas dan antioksidan di dalam tubuh yang merupakan tanda dari stres oksidatif. ${ }^{9}$

Beberapa penelitian menunjukkan bahwa stres oksidatif berperan dalam inflamasi sistemik, gangguan sekresi sel $\beta$ pankreas, gangguan penggunaan glukosa pada jaringan perifer serta disfungsi endotel. Munculnya stres oksidatif pada DM terjadi melalui tiga mekanisme yaitu glikasi nonenzimatik pada protein, jalur poliol sorbitol (aldosa reduktase), dan autooksidasi glukosa. ${ }^{4}$ Stres oksidatif yang berlebihan akibat kelainan dalam metabolisme glukosa dapat dikontrol dengan pengaturan asupan makanan terutama sumber antioksidan. ${ }^{4,} 6$ Selain itu, pengendalian DM berupa kombinasi obat multipel dan perubahan gaya hidup mampu berperan dalam pencegahan komplikasi vaskular akibat stres oksidatif serta menurunkan angka morbiditas akibat penyakit kardiovaskular dan penyebab lain pada penderita DM tipe $2 .{ }^{9}$

Pada penelitian ini, tampak bahwa mayoritas asupan makanan sumber vitamin $C$ dan vitamin $E$, termasuk dalam kategori defisit atau kurang dari kebutuhan yang dianjurkan. Nilai median asupan vitamin $\mathrm{C}$ responden 84,7 mg (10 - 545,4 mg). Menurut rekomendasi RDA, dosis vitamin $\mathrm{C}$ yang diperlukan bagi pencegahan penyakit kronik adalah $120 \mathrm{mg} / \mathrm{hari}^{10}$ Sumber lain menyebutkan rekomendasi dosis harian pada gangguan insulin endokrin atau diabetes mellitus sebesar 1000-3000 mg. ${ }^{11}$ Sebuah penelitian menunjukkan bahwa 
suplementasi vitamin C sebesar 1000 $\mathrm{mg} /$ hari dapat memberikan efek penurunan glukosa plasma pada pasien DM tipe $2 .{ }^{12}$ Penelitian lain menunjukkan bahwa pemberian suplementasi vitamin $C$ sebesar 266,7 mg/hari dan vitamin E 300 IU terbukti mampu menurunkan kadar glukosa darah puasa. $^{8}$

Rendahnya asupan makanan sumber antioksidan pada responden dalam penelitian ini disebabkan oleh banyak faktor. Salah satu faktor penyebabnya adalah terkait pemilihan bahan makanan. Misalnya dalam hal pemilihan bahan makanan sumber vitamin $\mathrm{C}$, yang banyak dikonsumsi oleh responden antara lain buah pepaya, pisang, jeruk, tomat dan apel. Hasil SQ FFQ menunjukkan bahwa responden jarang mengonsumsi jambu biji yang kaya akan vitamin C, yaitu sebesar $95 \mathrm{mg} / 100 \mathrm{~g}$ buah jambu biji. ${ }^{13}$ Kandungan vitamin $C$ pada buah jambu biji hampir 2 kali lebih banyak daripada jeruk manis $(44 \mathrm{mg} / 100 \mathrm{~g}), 4$ kali lebih banyak dari apel $(20 \mathrm{mg} / 100 \mathrm{~g})$, dan 6 kali lebih banyak dari tomat $(17 \mathrm{mg} / 100 \mathrm{~g}){ }^{14}$

'Hasil analisis statistik menunjukkan bahwa tidak terdapat hubungan yang signifikan antara asupan vitamin $\mathrm{A}$ dengan kadar glukosa darah puasa $(p=0,185)$ pada penelitian ini. Walaupun tidak terdapat hubungan, tetapi jika dilihat dari nilai korelasi (r) menunjukkan angka negatif, hal ini menunjukkan tren semakin tinggi asupan vitamin A maka kadar glukosa darah semakin menurun. Hasil berbeda ditunjukkan oleh penelitian lain di Perancis bahwa pemberian suplementasi antioksidan selama 7,5 tahun tidak berpengaruh pada kadar glukosa darah puasa pada pria atau wanita yang mengikuti diet seimbang, tetapi ditemukan hubungan antara asupan karoten dengan kadar glukosa darah puasa. ${ }^{15}$ Penelitian lainnya juga menyebutkan bahwa di antara karotenoid tunggal, asupan betacryptoxanthin secara bermakna berkaitan dengan penurunan risiko DM tipe 2 (RR
0,58, 95\% Cl 0,44-0,78, $p<0,001) \cdot{ }^{7}$ Hasil studi kasus-kontrol juga menunjukkan bahwa kadar plasma beta-karoten yang tinggi berhubungan dengan rendahnya risiko diabetes. ${ }^{16}$

Vitamin A (retinoid) memiliki fungsi sebagai antioksidan yang dapat membantu mempertahankan homeostasis organisme ketika mengalami berbagai bentuk stres. Retinoid berperan dalam metabolisme hepatik lipid, adipogenesis serta fungsi sel $\beta$ pankreas. Sementara retinol binding protein (RBP), protein pengangkut retinoid, mempunyai efek penting pada sensitivitas insulin yang bertindak sebagai adipokine. ${ }^{17}$ Fungsi vitamin A pada DM tipe 2 yaitu memperbaiki resistensi insulin dengan cara memblok TNF-a dan meningkatkan fungsi Glut-4 transporter yang membawa glukosa darah masuk ke dalam sel sehingga jumlahnya dalam darah menjadi normal. ${ }^{18}$ Vitamin A terdiri dari berbagai komponen kimia dengan kesamaan struktural dan fungsional. Bentuk yang paling aktif adalah retinol, ditemukan pada jaringan hewan, diesterifikasi dengan asam lemak rantai panjang. sedangkan karoten yang terdapat dalam jaringan tumbuhan enzimatik dihidrolisis menjadi retina dan diubah menjadi retinol di enterosit. Beberapa xanthine diubah menjadi retinol. ${ }^{17}$

Vitamin A dalam makanan sebagian besar berasal dari sumber makanan nabati dan hewani. Sumber vitamin A yang sudah terbentuk (retinol) dalam makanan meliputi hati, susu dan produk susu, telur serta ikan. Senyawa karotenoid provitamin A ditemukan pada makanan nabati yang berwarna kuning, orange, dan hijau. ${ }^{19}$ Pada penelitian ini mayoritas responden (123 responden) sudah memenuhi kebutuhan sehari berdasarkan AKG yaitu $600 \mathrm{mcg}$, karena belum ada secara khusus dosis vitamin $A$ yang dianjurkan untuk penderita DM. Berdasarkan hasil statisitik ditemukan tidak ada hubungan antara asupan makanan 
sumber vitamin A dengan kadar glukosa darah puasa, jadi berbeda dengan hasil penelitian-penelitian lain. Hal ini bisa dipengaruhi oleh beberapa hal yang menyebabkan vitamin A kurang berperan, misalnya adanya defisiensi vitamin $A$ di dalam tubuh, walaupun asupan dari luar cukup. Defisiensi vitamin A dapat disebabkan oleh beberapa faktor, antara lain yaitu adanya defisiensi protein dan $\mathrm{Zn}$ yang bisa menghambat pelepasan vitamin $\mathrm{A}$ dari hati, adanya gangguan dalam proses penyerapan di dalam usus halus, terdapat gangguan penyimpanan di hati, serta gangguan dalam proses konversi pro vitamin A menjadi vitamin $A .{ }^{20}$

Hasil penelitian ini juga menunjukkan bahwa asupan vitamin $\mathrm{C}$ tidak berhubungan secara signifikan dengan kadar glukosa darah puasa responden $(p=0,057)$. Hasil ini didukung oleh penelitian lain yang menyebutkan bahwa tidak ada hubungan antara asupan vitamin $\mathrm{C}$ dengan risiko terjadinya DM tipe 2.7 Hasil berbeda ditunjukkan dalam penelitian Dakhale et al. pada pasien DM tipe 2 yaitu kelompok dengan penambahan suplementasi vitamin C sebesar $500 \mathrm{mg}$ sebanyak dua kali sehari selama 12 minggu. Penelitian tersebut menunjukkan hasil kadar $\mathrm{HbA1c}$, glukosa darah puasa dan 2 jam post prandial yang lebih rendah jika dibandingkan dengan kelompok yang diberi plasebo, meskipun semua kelompok baik yang diberi plasebo atau suplemen telah diberi metformin. ${ }^{21}$

Manusia tidak dapat memproduksi vitamin $C$ dalam tubuh karena tidak memiliki enzim oksidase L-gulonolactone yang mengkatalisis langkah terakhir dalam sintesis asam askorbat sehingga perlu asupan dari luar tubuh melalui makanan. Vitamin $\mathrm{C}$ merupakan zat gizi penting bagi manusia yang bertindak sebagai agen pereduksi dalam proses oksidasi radikal bebas, sehingga dapat dikatakan bahwa vitamin C dapat bertindak sebagai antioksidan. ${ }^{22}$ Peran vitamin C atau asam askorbat pada diabetes adalah sebagai inhibitor enzim aldose reduktase, sehingga penggunaan ekuivalen pereduksi berkurang. ${ }^{10}$ Kesediaan ekuivalen pereduksi berguna untuk konversi glutation teroksidasi (GSSG) menjadi glutation tereduksi (GSH). Hal inilah yang selanjutnya dapat mencegah penumpukan sorbitol dalam jaringan. Manfaat lain penggunaan antioksidan adalah meminimalisasi pembentukan AGEs (advance glycosylation end products). Kondisi tersebut dianalogkan dengan penggunaan vitamin $C$ dalam meminimalisasi proses browning pada makanan. Mekanisme meminimalkan pembentukan AGEs tidak terlepas dari peran vitamin $C$ pada jalur poliol sorbitol (aldose reduktase). Pengurangan penumpukan sorbitol di jaringan akan menekan fruktosa sehingga proses glikasi nonenzimatik juga ditekan. ${ }^{4}$

Hasil penelitian ini yang menunjukkan tidak terdapat hubungan antara asupan makanan sumber vitamin $\mathrm{C}$ dengan kadar glukosa puasa diduga dipengaruhi oleh perubahan nilai vitamin $\mathrm{C}$ yang masuk ke dalam tubuh. Asam askorbat (vitamin C) dapat hilang selama penyimpanan buah dan sayuran serta ketika proses persiapan dan pemasakan makanan. Hal ini sebagian disebabkan oleh proses oksidasi dan sebagian lagi karena terlarut dalam air yang digunakan untuk memasak. ${ }^{13}$ Dengan berkurangnya nilai vitamin yang masuk ke dalam tubuh, membuat fungsinya pun akan menurun dalam pengendalian kadar glukosa darah.

Hasil penelitian ini juga menunjukkan bahwa tidak terdapat hubungan antara asupan vitamin $E$ dengan kadar glukosa darah puasa $(p=0,211)$, tetapi nilai korelasi menunjukkan angka negatif yaitu semakin tinggi asupan vitamin E maka kadar glukosa darah puasa akan semakin turun. Penelitian lain melaporkan bahwa asupan vitamin $\mathrm{E}$ 
secara bermakna berhubungan dengan penurunan risiko DM tipe 2 ( $R R=0,69,95 \%$ $\mathrm{Cl} 0,51-0,94, p=0,003)$. Hasil penelitian tersebut menunjukkan bahwa asupan alphatocopherol, gamma-tocopherol, deltatokoferol, dan beta-tocotrienol berbanding terbalik dengan risiko terjadinya DM tipe $2 .{ }^{7}$

Vitamin E pada kondisi diabetes bekerja dengan cara memperbaiki potensi sistem pertahanan radikal bebas dan memiliki efek menguntungkan dalam perbaikan transpor glukosa serta sensitivitas insulin. Selain itu, pemberian vitamin $E$ sebanyak $600 \mathrm{mg} / \mathrm{hari}$ selama 4 minggu dapat meningkatkan level GSH (glutation tereduksi) sel darah merah dan rasio glutation tereduksi (GSH) atau glutation teroksidasi (GSSG) plasma. Vitamin E juga bereaksi dengan antioksidan larut air seperti glutation. ${ }^{4}$ Penelitian ini menunjukkan bahwa asupan makanan sumber vitamin $\mathrm{E}$ tidak berhubungan dengan kadar glukosa darah puasa, disebabkan karena rendahnya asupan vitamin E pada responden. Dibandingkan dengan hasil penelitian Rafighi et al., asupan vitamin E responden dalam penelitian ini tergolong sangat kurang untuk pengendalian kadar glukosa darah karena nilai median asupan vitamin $E$ responden hanya $3,9 \mathrm{mg}(0-10,9 \mathrm{mg})$ atau setara dengan 5,8 IU, sedangkan rekomendasi dosis harian pada pasien dengan gangguan insulin endokrin yaitu sebesar 200-1500 IU.8,11

Sumber vitamin $\mathrm{E}$ dapat diperoleh dari minyak sayur hasil proses ekstraksi dari bijibijian atau buah-buahan seperti minyak jagung, minyak kedelai, minyak biji gandum serta minyak zaitun. ${ }^{14}$ Pemenuhan $200 \mathrm{IU}$ vitamin $E$ per hari cukup sulit dipenuhi jika hanya bersumber dari asupan makanan, oleh karena itu dibutuhkan suplementasi vitamin E. Pemberian suplementasi zat gizi mikro sumber antioksidan pada penderita DM secara teratur sangat penting dalam pencegahan dan pengobatan komplementer, mengingat tingginya insiden komorbiditas. ${ }^{11}$

Tidak ditemukannya hubungan antara asupan makanan sumber antioksidan (vitamin $A$, vitamin $C$, dan vitamin $E$ ) dengan kadar glukosa puasa pada penelitian ini, selain karena berkurangnya nilai antioksidan, kemungkinan juga disebabkan oleh beberapa faktor lain yang lebih berperan dalam pengendalian kadar glukosa darah puasa penderita DM tipe 2 di Jawa Timur yang menjadi responden. Kadar glukosa darah puasa merupakan hasil dari tes glukosa darah puasa yang digunakan untuk menguji efektivitas obat atau makanan yang dikonsumsi orang yang sudah didiagnosa diabetes. Dikatakan terkendali jika kadar glukosa darah puasa pada pasien yang sudah menderita DM sebesar 80-126 $\mathrm{mg} / \mathrm{dL} .{ }^{3}$ Pada penelitian ini ditemukan bahwa mayoritas kadar glukosa darah puasa responden termasuk dalam kategori tidak terkendali (>126 mg/dL) yaitu sebanyak $73 \%$.

Terdapat empat pilar yang berperan dalam pengendalian kadar glukosa darah pada pasien DM tipe 2 yaitu edukasi atau penyuluhan, perencanaan makan, latihan jasmani, dan obat atau terapi farmakologi. ${ }^{1}$ Hasil penelitian Sutiawati et al., menunjukkan edukasi gizi berpengaruh terhadap peningkatan pengetahuan secara berkala pada pasien DM serta dapat mengontrol kadar glukosa darah $(p=$ $0,000){ }^{23}$ Menurut Rachmawati, dengan adanya latihan jasmani dapat menurunkan atau mengendalikan kadar glukosa darah pada penderita DM tipe2.. ${ }^{24}$ Selain edukasi dan latihan jasmani, kadar glukosa darah juga dapat dikendalikan dengan perencanaan makan yang baik terutama dalam pengaturan zat gizi makro. Penelitian menunjukkan bahwa ada hubungan yang signifikan antara total energi yang dikonsumsi dengan kadar glukosa darah puasa $(p=0,000) .{ }^{25}$ Penelitian Schulze et al. 
juga menunjukkan konsumsi tinggi minuman manis berisiko lebih besar terhadap kenaikan berat badan dan meningkatkan risiko pengembangan DM tipe 2 pada wanita, kemungkinan dengan menyediakan energi yang berlebihan dan dalam jumlah besar gula cepat diserap oleh tubuh. ${ }^{26}$

\section{Kesimpulan}

Kendali glikemik berupa kadar gula darah puasa (GDP) penderita DM tipe 2 yang menjadi responden dari 4 kota dan kabupaten di Jawa Timur mayoritas belum terkendali atau terkontrol. Rata-rata asupan makanan sumber vitamin $\mathrm{C}$ dan vitamin $\mathrm{E}$ responden masih kurang dari kebutuhan, sedangkan asupan vitamin A mayoritas responden sudah baik. Tidak terdapat hubungan antara asupan makanan sumber antioksidan yaitu vitamin $\mathrm{A}$, vitamin $\mathrm{C}$, dan vitamin $\mathrm{E}$ dengan kadar glukosa darah puasa.

\section{Daftar Pustaka}

1. Rudijanto A, Yuwono A., Shahab A., Manaf $A$, Pramono $B$, Lindarto $D$, dkk. Konsensus Pengelolaan dan Pencegahan Diabetes Melitus Tipe 2 di Indonesia 2015. Jakarta: PB Perkeni. 2015. p 1-3.

2. Departemen Kesehatan RI. Laporan Riset Kesehatan Dasar Tahun 2013. Jakarta: Badan Penelitian dan Pengembangan Kesehatan Departemen Kesehatan RI. 2013.

3. Soegondo S, dkk.. Penatalaksanaan Diabetes Mellitus Terpadu. Jakarta: Fakultas Kedokteran Universitas Indonesia. 2011.

4. Setiawan,B dan Suhartono E. Stres Oksidatif dan Peran Antioksidan pada Diabetes Mellitus. Maj Kedokt Indon. 2005; 55 (2):86-91.

5. Roxana VR, Guadarrama LAL,
MartínezCBE, and Benítez AAD. Vitamins and Type 2 Diabetes Mellitus. Endocrine, Metabolic \& Immune Disorders - Drug Targets. 2015; 15:5463.

6. Baynes JW and Thorpe SR. Role of Oxidative Stress in Diabetic Complications: A New Perspective on an Old Paradigm. Diabetes. 1999; 48:19.

7. Montonen J, Knekt P, J"Arvinen R., Reunane A.Dietary Antioxidant Intake and Risk of Type 2 Diabetes. Diabetes Care. 2004; 27:362-366.

8. Rafighi Z, et al. Association of Dietary Vitamin $C$ and $E$ and Antioxidant Enzym in Type 2 Diabetes Mellitus Patients. Global Journal of Health Science. 2013; 5(3).

9. Zatalia SR and Sanusi H. The Role of Antioxidants in The Pathophysiology, Complications and Management of Diabetes Mellitus. Acta Med Indones. 2013; 45(2):141-147.

10. Cunningham JJ. The Glucose/Insulin System and Vitamin C: Implications in Insulin-Dependent Diabetes Mellitus. $J$ Am Col of Nutr. 1998; 17(2):105-8.

11. Grober U. Mikronutrien Penyelarasan Metabolik, Pencegahan dan Terapi. Jakarta: EGC . 2012. p 236-240.

12. Afkhami $M$ and Shojaoddiny. Effect of Vitamin $C$ on Blood Glucose, Serum lipid and serum Insulin in Type 2 Diabetes patient. Indian $\mathrm{J}$ Med Res. 2007.(online).

http://medind.nic.in/iby/t07/i11/ibyt07i11 p471.pdf.

13. Lean MEJ. 2013. IImu Pangan, Gizi,\& Kesehatan. Yogyakarta: Pustaka Pelajar. 2013. p 430 - 465.

14. Almatsier S. Prinsip Dasar IImu Gizi. Jakarta: Gramedia. 2009.

15. Czernichow $S$, Couthouis A, Bertrais $S$, Vergnaud AC, Dauchet L, Galan P, and Hercberg S. Antioxidant 
Supplementation Does Not Affect Fasting Plasma Glucose in the Supplementation with Antioxidant Vitamins and Minerals (SU.VI.MAX) Study in France: Association with Dietary Intake and Plasma Concentrations . Am J Clin Nutr. 2006; 84:395-9.

16. Reunanen $A$, Knekt $P, A a r a n ~ R K$, and Aromaa A. Serum Antioxidants and Risk of Non-Insulin Dependent Diabetes Mellitus. Eur J Clin Nutr. 1998; 52(2):89-93.

17. Brun PJ, Yang KJ, Lee SA, Yuen JJ, and Blaner WS. Retinoids: Potent Regulators of Metabolism. Biofactors. 2013; 39(2):151-163.

18. Widiowati W. Potensi Antioksidan sebagai Antidiabetes. Jakarta: JKM. 2008.

19. National Academy of Science. Dietary Reference Intake. Washington. DC: National academy press . 2003.

20. Muchtadi D. Gizi Anti Penuaan Dini. Bandung: Alfabeta. 2009. p 25-26.

21. Dakhale GN, Chaudhari HV, Shrivastava M. Supplementation of Vitamin C Reduces Blood Glucose and Improves Glycosylated Hemo-Globin in Type 2 Diabetes Mellitus: A Randomized, Double-Blind Study. Adv Pharmacol Sci. 2011:195271.

22. Mandl J, Szarka A, Bánhegyi G. Vitamin C: Update on Physiology and Pharmacology. $\mathrm{Br} J$ Pharmacol. 2009;157(7):1097-1110.

23. Sutiawati M, Jafar N, Yustini.Pengaruh Edukasi Gizi terhadap Pengetahuan, Pola Makan dan Kadar Glukosa Darah Pasien Diabetes Melitus Tipe 2 RSUD Lanto' Dg Pasewang Jeneponto. Media Gizi Masy. Indones. 2013; 2:78-84.

24. Rachmawati O. Hubungan Latihan Jasmani terhadap Kadar Glukosa Darah Penderita Diabetes Mellitus Tipe 2. Tugas Akhir. Tidak Diterbitkan.
Surakarta: Fakultas Kedokteran Universitas Sebelas Maret. 2010.

25. Wirawanni $Y$ dan Immawati FR. Hubungan Konsumsi Karbohidrat, Konsumsi Total Energi, Konsumsi Serat, Beban Glikemik dan Latihan Jasmani dengan Kadar Glukosa Darah pada Pasien Diabetes Mellitus Tipe 2. Journal of Nutrition and Health. 2014; 2(3).

26. Schulze MB, Manson JE, Ludwig DS, et al. Sugar-Sweetened Beverages, Weight Gain, and Incidence of Type 2 Diabetes in Young and Middle-Aged Women. JAMA. 2004 ; 292 (8):927-934. 